\title{
Library Management: an Overview of Its Past, Present, and Future
}

\author{
Corneliu Făgărășan \\ PhDc, Technical University of Cluj-Napoca \\ E-mail corneliu.fagarasan@gmail.com
}

In the light of understanding the complex process of developing a library and of the future of the field, this article proposes to capture the main elements of organizing libraries from the past and present, so that we can be able to develop a prognosis over the way they will look like. Is there a way that the tablet guard in a Babylonian library from $700 \mathrm{BC}$, the armarius that took care of the VIII century cathedral-school library from York and the director of academic resources belonging a university would recognize each other as belonging to the same profession? The main goal the article is to oversee the development of the library management, using several objectives as viewing it through different perspectives.

Keywords: library management; library history; library associations; digital library projects

\section{Introduction}

The ancient librarian who made, in the best case, lists of shelves and invoked different gods for the protection of the tablets, the Middle Age librarian who compiled a catalog and chained the books by the library tables and the XXI century librarian in whose obligation could enter online cataloging and installing anti-theft systems, they would all have something in common. Even the use of digital information would not totally disturb previous XXI century librarians as they noticed the triumph of codices over the papyrus scrolls, the evolution of paper and the invention of printing. However, history has seen changes in answering questions like "who manages the library?", "what he/she manages?", "how?", "with what technologies?", "for whom and with what management notions?" The most important change in the management of libraries is the change from one focus towards the inside, to one focused outwards, a change from the individual leadership to a collective leadership.

\section{Library management in the past}

Since the third millennium BC, the kings of Mesopotamia gathered writings on cuneiform engraved clay tablets, largely used by the temple clergy and the scribes of schools. The acquisition was made more by confiscation, in times of conquests or, in the most peaceful case, by gifts offered to them by the traveling submitted envoys. Librarians that were scribes had the task of translating some of the works or to copy, organize and place them in boxes and position them on shelves, every room having a list of their contents. Moreover, they had bibliographical control and the responsibility to preserve them as evidence shown even in the library of Ashurbanipal in Assyria (Casson, 2001).

Similar libraries were built in ancient Egypt although there is less evidence to support this fact, because the favorite material of keeping the information at that time was papyrus, and it deteriorated much faster than clay tablets. However, there is evidence to support the fact that libraries where admired, for example an inscription that says the library was "The place of soul cleansing" (Harris, 1999 p. 28). In Egypt and Ancient Greece, an additional task attributed to librarians was the maintenance of faithful duplication of religious texts, but in Athens, also of the

Revista Română de Biblioteconomie şi Ştiința Informării = Romanian Journal of Library and Information Science ISSN 2559-5490, ISSN-L 1841-1940 • Volume 13 Issue 22017 pp. 47-52 https://doi.org/10.26660/rrbsi.2017.13.2.47

This work is licensed under a Creative Commons Attribution-NonCommercial-NoDerivatives 4.0 International License 
acclaimed theatre plays. In Ancient Greece, which had many libraries, their administration, like many other things, had Aristotle's full attention. He had created a system for arranging his own large library, a system that was later on passed to others as well.

The development of the ancient library culminated with the famous library of Alexandria from the third century $\mathrm{BC}$, its administrators accepting extensive responsibilities. They had to collect intensively at least Greek-language works and give access to all renowned scholars. The Ptolemy government named the head librarians, who probably managed slaves, whose duty was also likely to teach royal family children. Many of Alexandria's librarians were scholars who produced bibliographies, criticism, lexicography and grammar works. Probably the most important thing to remember is that they have developed the administration of libraries by introducing the use of the alphabetical order and have designed easier ways to use and store the scrolls on which the works were written.

In Rome, the library director, known at that time as the bibliothecarum procurator, was the one who oversaw budgets, handled acquisitions and worked as head of individual libraries and their staff. This included copiers, catalogers, translators, custodians, clerks, restorers.

The Codex, with its book-like parchment pages, gradually replaced the papyrus scrolls on the bookshelves. This has facilitated the management of libraries. Codices had storage and referencing advantages and, in order to find information, one had to browse the pages instead of unrolling the fragile scrolls and rolling them back.

Rome's libraries suffered with its decline, surviving only in the eastern part of the empire, for example serving the palace and University of Constantinople and the growing number of Christian monasteries. Cassiodorus, who lived in the sixth century, was the one during which it was determined how manuscripts should be manipulated, corrected, copied and repaired. He had even set up a considerable library and promoted the value of copying both pagan and religious works, allowing for interlibrary lending. In his days and after them, the propagation of duplicates made it possible to preserve manuscripts despite the frequent destruction of libraries during the wars, natural catastrophes and political or religious intolerance. With the efforts of Cassiodorus, many classical works have survived to become the intellectual basis of the Western Renaissance.

In the Middle Ages of the West, schools near cathedrals developed small sized libraries, each kept in cabinets called armarium. The rules of the English monastic libraries emphasized that: "the first task of a librarian, in his time, is to strive as much as possible to increase the library that is entrusted to him. Make him be aware that the library is not restraining... Make him fix the books destroyed by time by tying them. Make him know the names of their authors" (Harris, 1999 p. 101).

Probably the first record of the admonition on silence or tranquility in a library was made in the seventh century by a bishop of Seville (Harris, 1999 p. 94). When the Christian Council of the church gathered, they found the papal library so well organized that they congratulated their librarian. It was only until the fifteenth century that an Augustine monk had the first idea of composing a true veritable catalog of books from all the monasteries of England.

The invention of the printing press from the fifteenth century helped the management of the library make the purchasing process of books cheaper and easier, by multiplying their copies, but also their new shape meant that they were easier to keep. Printing has relieved libraries of the need to continue copying as a major activity, but the multiplication of the number of books available has transformed the librarianship into a much more complex job.

In the nineteenth century, national libraries appeared, along with the Bibliotheque Nationale de France, after the French Revolution. Many of these national libraries have grown from royal libraries, augmented by gifts, forfeits, conquests and legal deposits laws. Managers had to organize large inflows of information and give users access to it. The most important managers who influenced the library system included Sir Antonio Panizzi, the bookkeeper of the British Library. 
He encouraged the development of catalogs and added a new management function - he lobbied Parliament to raise funds.

Managerial professionalism had also increased. In the United States, the mid 1880's meant the creation of the American Library Association, the publication of Library Journal and the publication of the articles by the top librarian authorities in a report (Public Libraries in the United States of America) which became the standard librarians' manual. Also, at the end of the nineteenth century, top librarians developed library educational courses and after that library schools. With new reasons - public moral lifting, educating a democratic electorate and the Americanization of immigrants - professional library managers have widened the library clientele, opened the deposits, increased the work schedule, provided the referencing service, and with the twentieth century they moved into new buildings. Expansion also took the form of traveling libraries, through which Canadian librarians managed to reach out to people living far away or in scattered settlements (Marcum, 2009 p. 3377).

In Europe, unfortunately, the management of the twentieth century libraries has meant something else, the need to cope with growth and decline cycles, destruction and reconstruction, spread and reorganization as a result of the economic crisis and the two world wars. In some countries, management was understood as control of what people are reading, making state promotion or party ideologies the basis of purchasing decisions. In America, the refusal of raising budgets during the Great Depression (1929-1933) complicated their management, but library managers had made improvements by developing tools such as microformat storage, cooperative purchasing, unit cataloging and an interlibrary loan system. After the end of the Second World War, academic libraries together with their educational institutions faced a new managerial challenge - the need to educate thousands of military veterans who took advantage of the G.I. Bill (Murray, 2014) to get schooled. This kind of mass reward was inconceivable for King Ashurbanipal for example, and certainly encouraged librarians to abandon the concept adopted for centuries in which the library was the founder of the safeguard of the privileged few.

\section{Modern library management}

A monologue of late-twentieth century librarians, beginning in the twentieth century, would sound like this: "If we are going to survive and compete in the new environment, we will have to work smarter, reinvent the organization, re-engineer our own work processes, become proactive rather than reactive, and, above all, orient ourselves strategically" (Marcum, 2009 p. 3377).

This would mean that there is a need for a strategic plan, a clear vision, a common mission with measurable results and objectives, identifying inputs and outputs. Also, there should be built a plan for risk assessment, impact assessment, feedback and responsibilities network/circuits in the organization.

This shift in management has brought with it new ways of thinking. The old "patrons" of the library have become "customers" with whom the library should connect and whose expectations should be overcome by librarians.

"The duties of a library executive do not differ in any way from the duties of a joint stock company manager (...) the librarian could benefit from the methods of a businessman" (Drury, 1924 p. 83). In the second half of the twentieth century librarians have begun to listen to the ideas of the "scientific management", manifested in the industry by researching efficiency in production planning, standardization, staff selection and educational studies (Harris, 2006 p. 109). As time passed, librarians have introduced ideas for improving the system and created organizational diagrams, job descriptions, policy manuals and procedures. Librarians also have considered new visions of the influence of the human factor in productivity, studying working conditions, reward recognition methods, personal fulfillment opportunities, and how staffs respond to social 
workplace relationships. The vast majority of libraries have adopted business concepts such as "customer service". Cost analyzes, system analyzes and decision theories have also attracted some library managers (Stueart and Moran, 2002 p. 4).

Faced with this "jungle of management theory" (Koontz, 1961 p. 174), the modern library management can be forgiven many times because it creates confusion in its organization.

There is, of course, no unity of vision regarding the modern management issues of libraries. Library managers have opposing views on issues such as "all books are equal", or "growing workload increases library usage", or "all children know how to use the computer" (Holt, 2005, p. 87). Survival requires thus recognition of library methods of change, methods that are generally accepted and also methods offered by the IT industry (Dysart, 2005 p. 131).

In USA, help comes to librarians from the multitude of professional associations that are grouped under the American Library Association (ALA), divisions that include the Library Administration and Management Association (at present Library Leadership and Management Association LLAMA), established in 1957. This helps librarians stay informed about problems and management techniques through publications, meeting programs and special interest sections. In addition to other ALA divisions that help managers, the Public Library Association (PLA) offers a library administration and certification program.

Librarians of large universities receive help from the Association of Research Libraries (ARL), which in 1970 created a management study bureau responsible for drafting library resources guides while they are in line with ongoing change in management issues.

In the US, help comes also alongside the professional journals such as American Libraries, Library Administration and Management, Library Hotline, Library Journal and Library Trends that inform and promote professional library management, and from the part of federal and state libraries, library consortia's, private organizations such as the Council on Library and Information Resources (CLIR) and libraries and information science schools, which launch specialists in the future.

Until the end of the twentieth century, financial issues and the development of IT technology have forced some of the librarian education schools to close and others to be assimilated by larger libraries or information science schools. MLS or MLIS are master's degrees in librarianship or information sciences, diplomas that have become the accreditation basis for ambitious librarians, and in 2006, Simmons College received a grant to develop a doctoral program in "Managerial Leadership in Information Professions" (Hernon and Schwartz, 2006 p. 1). Leadership in general has become a specialized study where librarians' publications have begun to pay attention to since the late 1980s, arguing for the existence of successful library management features.

It is therefore appropriate to come up with a series of questions about the present management of libraries, such as:

a) Can education programs in library management produce enough new library leaders?

b) Can they replace the old ones?

c) Do they have a sufficient broad vision, openness to change, flexibility and tactics necessary for success in the long run?

\section{Future library management}

Libraries have radically changed in response to the development of digital information technology. Until the beginning of the twenty first century, librarians of all types automated business functions and logs, created web pages, created online catalogs, participated in the unification of online catalogs, subscribed to electronic databases, installed computers for users, added CDs to audiovisual collections and began to worry about whether the Internet would make their jobs, 
buildings and books outdated.

In large institutions, librarians have digitalized some of their info-documentary materials, put digital resources on their web pages, collected digital products of scientists in electronic warehouses, provided reference services through e-mail, collaborated to create digital educational resources, have set up electronic courses, strengthened libraries with IT and educational technology, have tried to find ways to preserve digital resources in the long run, and have begun to wonder whether digital creations fall under intellectual property laws. All of these have become major managerial concerns.

Therefore, library management will change a lot, whereas the creation of digital libraries collaboration, libraries that share their collections of info-documentary materials with worldwide access, will further expand the storage capacity of information media. It all began with the evolution of digital collections, such as the digital collection of American books, which Cornell and the University of Michigan have done pioneering in creating: The Digital Memory Collection of America at the Library of Congress at which other American libraries have participated; and the Global Gateway Bilingual Collection on the Library of Congress webpage that combines digitized materials about some foreign countries with materials from national libraries and other libraries of those countries (Marcum, 2009 p. 3380).

With something more important in mind, a group of major research libraries (including the Library of Congress) and other related organizations from the United States have set up the Digital Library Federation (DLF). It has the task of gathering digitized information documents that will be accessible to students, researchers and citizens everywhere. The Federation later expanded to library organizations from other countries such as the British Library and launched the DLF Aquifer Project that promotes the efficient use of distributed digital library content for education, learning and research. Aquifer will provide a single web page with a portal for digital library collections of multiple libraries and will use this body of materials to develop "the best search, identification and use of digital resources" (Bennet et al., 1995; Digital Library Federation, 2005).

Europeans have created TEL - The European Library that offers universal online access to digital collections from 47 national libraries. In 2006, UNESCO, IFLA (the International Federation of Library Institutions and Associations) and the Library of Congress began planning WDL - World Digital Library to "make accessible, free and on a multilingual basis, significant primary material from cultures around the globe" (World Digital Library, 2010). Google Corporation began digitizing at least parts of the largest libraries and archiving for their access through their search engine, declaring its intention "to organize the world's information and make it universally accessible and usable" (Thompson, 2017). In short, libraries collaborate with each other, developing commercial search services and other organization, both non-profit and for profit, to digitize personal resources and universalize access to them, being in a permanent expansion of their activities.

\section{Conclusions}

In the twenty first century, the specific process of constructive cooperation of a digital library system requires the financial, storage and access collaboration. The process may turn out to be as the present article would like to prove as being a gradual one, depending on how long digitization will take, improving interoperability tools, resolving copyright issues, resolving storage issues, expanding internet accessibility, increasing resource organization, refining search capabilities and designing business partnerships, that will act as connecting nodes more than enclaves defined by walls. These are the major concerns of the twenty first century managers and all of these need external collaborations. Librarians with vision will worry less about preserving "the king's consent", and they will be concerned about sharing what is useful to the world. So a further research in the present field would be regarding new ways librarians might share their knowledge 
on developments of the library management methods, especially because this is currently a shortcoming of the present theme, due to the fact that new methods of leadership in this field are always questioned until they prove their validity and become a general practice.

\section{References}

Bennet, S. et al. (1995) America's Heritage: Mission and Goals for a Digital Library Federation, available: https://old.diglib.org/about/dlfcharter.htm [accessed 25 January 2017].

Casson, L. (2001) Libraries in the Ancient World, New Haven: Yale University Press.

Corneanu, O. (2013) De la meseria de bibliotecar la cea de specialist în științele informării [From librarian to information science specialist], Educație și cultură, 8, available: http://ccdmures.ro/ cmsmadesimple/uploads/file/rev8sp/lbrom3.pdf [accessed 25 January 2017].

Digital Library Federation (2005) About the DLF, available: https://old.diglib.org/aquifer [accessed 28 January 2017].

Drury, G.G. (1924) The Library and Its Organization, New York: H.W. Wilson.

Dysart, J.I. (2005) Why libraries fail and tips for staying alive, Feliciter Journal, 51(3), pp. 131134.

Harris, M.F.W. (2006) F.W. Taylor and the legacies of systemization, Information, Communication \& Society, 9(1), pp. 109-120, available: https:// doi.org/10.1080/13691180500520017 [accessed 28 January 2017].

Harris, M.H. (1999) History of Libraries in the Western World, Lanham: Scarecrow Press.

Hernon, P. and Schwartz, C. (2006) Leadership: a unique focus, The Journal of Academic Librarianship, 30(1), pp. 1-2, available: https://doi.org/10.1016/j.acalib.2005.10.006 [accessed 28 January 2017].

Holt, G.E. (2005) Library myths that affect performance, The Bottom Line, 18(2), pp. 87-91, available: https://doi.org/10.1108/08880450510597532 [accessed 3 February 2017].

Koontz, H. (1961) The Management Theory Jungle, Academy of Management Journal, 4(3), pp. 174-188, available: https://doi.org/10.2307/254541 [accessed 26 January 2017].

Marcum, D. (2009) Library Management, Encyclopedia of Library and Information Science, $3^{\text {rd }}$ ed., Boca Raton: CRC Press, pp. 3375-3382, available: https://doi.org/10.1081/e-elis3-120043523 [accessed 8 February 2017].

Murray, P. (2014) What's a GI Joe?, available: http://learningenglish.voanews.com/a/leatherneckgrunt-doughboy-gijoe-marines/1873092.html [accessed 22 January 2017].

Stueart, R.D. and Moran, B.B. (2002) Library and Information Center Management, $6^{\text {th }}$ ed., Greenwood Village: Libraries Unlimited.

Thompson, A. (2017) Google's Vision Statement \& Mission Statement, available: http:// panmore.com/google-vision-statement-mission-statement [accessed 8 February 2017].

World Digital Library (2010) About the World Digital Library, available: https://www.wdl.org/en/ about [accessed 3 February 2017]. 